\title{
Effect of Credit Risk Management Practices on Financial Performance of Deposit Taking Savings and Credit Cooperatives in Kenya
}

\author{
Nancy Wanjiku Kariuki \\ (Jomo Kenyatta University of Agriculture and Technology, Kenya)
}

\begin{abstract}
The study analyzed the effect of credit risk management practices on financial performance of deposit taking SACCOs in Kenya by adopting descriptive research design and the population comprised of 164 SACCO registered under the SASRA. The objectives of the study was to establish the effect of credit risk identification, credit analysis practices, credit monitoring and credit mitigation measures on the financial performance of DTSs. Based on the study findings the study concluded that credit analysis, credit mitigation measures and credit risk identification have a significant positive effect on financial performance. The study recommended that SACCOs should have stringent credit analysis techniques and that it should also adopt credit monitoring practices. The study also recommended that SACCOs and any other credit lending organization should have a stringent credit mitigation measures and policies. Therefore the credit committees at all levels must work in co-ordination in order to ensure that credit is collected in a timely manner.
\end{abstract}

Keywords: Credit Risk, Credit Risk Management Practices, Deposit-taking Business, Loan Repayment

\section{Introduction}

According to the Sacco Supervision Annual Report Kenya (2014), there were a total of 181 licensed deposit-taking Sacco Societies (DTSs) however, 164 were registered to operate for the financial year ending 2016. Some of them had their deposit-taking licenses revoked and not renewed for the financial year 2016 due to persistent failure to address non-compliance issues which put to risk the interest of member deposits and financial sustainability of the deposit-taking business. One of the said issue involved credit risk management According to (Sambasivam, 2013), SACCOs amounts to about 34 percent of national savings and about 24 percent of outstanding domestic credit (CBK Report, 2011). SACCOs use these deposits to generate credit for their borrowers, which in fact are a revenue generating activity for most SACCOs. This follows that SACCOs face a number of risks and this has been a major cause of failure of many financial cooperatives (Sambasivam, 2013). This credit creation process exposes the SACCOs to high default risk which might lead to financial distress including bankruptcy. In the world of volatile cash movements and increasing global lending and borrowing of funds, few SACCOs if any remain unaffected by borrower's late and nonpayment of loan obligations. This result from the SACCO's inability to collect anticipated interest earnings as well as loss of principal resulting from loan defaults. SACCOs therefore need to carry out credit risk management as a measure of administering credit to borrowers by developing strategies to either eliminate or reduce this credit risk. In the management of this risk, SACCOs are concerned about their financial performance. However, despite the efforts made to address the poor credit risk management, SACCOs still have difficulties resulting from the credit risk management processes undertaken and changes in customer base leading to decreasing financial performance. Therefore, risk management as a discipline is being taken seriously.

The study has identified few local studies on credit risk management practices and financial performance of SACCOs. They include, Ngare (2008) who studied credit risk management practices by commercial banks and found that credit risk management has impact on performance of commercial banks, Sammy et al. (2013) analyzed the presence of financial mismatch in SACCOs leading to financial losses in the institutions, Muruti (2010), the Use Of 6 C's Credit Risk Appraisal Model And Its Relationship With The Level Of Nonperforming Loans Of Commercial Banks In Kenya. Muteru (2007) indicated that credit risk management practices impacted positively on performance of Pharmaceuticals manufacturing firms in Kenya. There is therefore a need to study the relationship between credit risk management practices and financial performance of SACCOs in Kenya. This study seeks to fill this gap of knowledge by investigating this relationship From the study, the financial industry is able to identify specific and the most effective practices to minimize loan portfolio losses other than blanket practices in credit risk management. This poses a more specialized risk management making it easier to detect risk the earliest. The research is valuable to the financial industry stakeholders and the SACCO management, it provided an insight into the best credit risk management practices that they can adopt in order to enhance performance in their industry. 
The research will help the government in policy making regarding taxation and other regulatory requirements of the SACCOs. New and potential investors can also use this research in planning staffing needs to their new investments in the industry. Unlike those who have entered the industry through try and error, the potential and new investors can emphasize on specific staff skills noted as crucial in minimizing loans losses.

The result of this research is invaluable to researchers and scholars, as it will form a basis for further study. The study is a source of reference material for future researchers on other related topics; it will also help other academicians who undertake the same topic in their studies. As the business environment keep on changing, prospective researchers may use this study to explore more dimensions of challenges to risk management in the broad spectrum financial institutions.

\subsection{SACCOs in Kenya}

The co-operative business model and structure has not changed much over the years, but the content and social dynamics are changing fast. The establishment of SACCO Societies Act 2008 places the licensing, supervision and regulation of deposit taking under the armpit of the SACCO Societies Regulatory Authority (SASRA). The SACCO sub sector comprises both deposit taking and non-deposit taking SACCOs. Deposits taking SACCOs are licensed and regulated by SASRA while non-deposit taking SACCOs are supervised by the Commissioner for Cooperatives. SASRA licenses SACCOs that have been duly registered under the Cooperative Societies Act CAP 490 (SASRA, 2012). Through this new legal framework, prudential regulations have been introduced to guide SACCO's growth and development (Barrales, 2012).

The Co-operative movement in Kenya is an important player in the social economic development of this country. Cooperatives cut across all sectors of the economy and provide an important framework for mobilization of both human and capital resources (Ministry of Co-operative Development and Marketing, 2008). According to the Sacco Supervision Annual Report (2014), there were a total of 181 licensed deposittaking Sacco Societies (DTSs) however 164 were registered to operate for the financial year ending 2016. Some of them had their deposit-taking licenses revoked and not renewed for the financial year 2016 due to persistent failure to address non-compliance issues which put to risk the interest of member deposits and financial sustainability of the deposit-taking business.

Alfred (2011), SACCOs have a high exposure to credit risk as well as operational risks (the risk of direct or indirect loss resulting from inadequate or failed internal processes, people and systems or from external events). With the population of Kenya at 40 million it is estimated that $63 \%$ of Kenyans participate directly or indirectly in cooperative development enterprises. Kenya has the largest SACCO movement in Africa with a total membership of 8 million followed by Senegal at 5 million. To date there are over 11,200 registered SACCOs in the country, with a membership of 8 million Kenyans having mobilized domestic savings estimated at over \$ 2.5 Billion. Of which 5,000 are SACCOs and 230 have Front Office Service Activities (FOSAs). The SACCO sector has mobilized over Kshs 200 billion in savings which is about $30 \%$ of the national savings (Njeru 2016)

The county's vision 2030 recognizes the role of financial services in mediating between borrowing and investment. The move to attain the vision 2030 has led to the government through the act of parliament to establish a regulatory body to oversee the operations of all SACCOs. However, access to financial services is a stumbling block which has led to low investment and high borrowing culture in Kenya. This is confirmed by the World Council of Credit Unions [WOCCU], 2008) that 38.3\% of the Kenyans are still not included in the use of financial services. The vision 2030 for financial services in Kenya can be fully achieved if SACCO members can transform their borrowing into viable investments. Hence, this study seeks to determine the determinants of financial performance of SACCOs in the Kenya and how Credit management practices affect them.

In the past, SACCOs have faced several challenges however Bessis (2003) states that risk management is one of the key aspects of corporate governance, particularly in the case of banks. The main risks faced by SACCOs are Market risk, interest rate risk, credit or default risk, operational risk and liquidity risk which every commercial bank is bound to face. Default risk has become the greatest of all and has eaten up available gains hence raising eye brows on how we give our loans. In SACCOs are not that different from other MFIs . In Kenya, some SACCOs have designed sound credit risk management practices in order to achieve their desired financial objectives. However, it may be difficult to establish an optimal credit management practices in SACCOs due to the frequent changes in economic conditions. According to Pandey (2008) SACCOs must develop credit management practices to govern their credit management operations and since SACCOs generate their revenue from credit extended to low income individuals in the form of interest charged on the funds granted from whom loan repayments may be uncertain. Studies show that many lending decisions by SACCOs are frequently based on their subjective feelings about the risk in relation to expected repayment by the borrower (Fayman \& He, 2011). In SACCOs commonly used credit risk management practices incorporates decision making process and on the financial data and judgmental assessment of the market outlook, borrower, management and shareholders. 
Credit risk is among the most critical risk to SACCOs and other FIs by the nature of its activity in terms of potential losses. The default of a small number of members may result in a very large loss for the SACCO (Bessis 2003). The SACCO Societies Act, 2008 establishes a Deposit Guarantee Fund (DGF) which shall provide protection to members deposits up to Ksh.100,000 per member (the same protection accorded depositors with banking institutions licensed under the Banking Act).

According to Opondo( 2014) financial organizations have been forced to hire external bodies or specialized persons to manage the credit risk where as this credit risk management practices can be established within the organization. This clearly brings in additional cost to the organization. Increasing profitability is a priority for all managers in FIs including SACCOs. On the one hand they also need to reduce the risk of loan default because SACCO viability is weakened by the loss of principal and interest, yet they operate under objectives of maximizing benefits to members which include the social role of providing loans to help members achieve their standard of living goals. This social roles conflict with their financial viability if managers become less stringent in the lending practices to assess and monitor the credit risk of member borrowers. This calls for the need to conduct more studies on credit risk management practices in SACCOs. The study is an attempt to close this gap by providing further insights and information on the effect of credit risk management practices on lending portfolios of SACCOs.

\subsection{Risk Management Theory}

\section{Literature review}

Wenk (2010), states that the Risk Management model consists of credit identification, credit assessment, and prioritization of risks followed by coordinated and economical application of resources to minimize, monitor, and control the probability and/or impact of unfortunate events or to maximize the realization of opportunities. Risks can come from uncertainty in financial markets, project failures, legal liabilities, credit risk, accidents, natural causes and disasters as well as deliberate attack from an adversary, or events of uncertain or unpredictable root-cause (Kirigo, 2014).

In practicing Risk Management, if risks are left unmanaged, they can cause a negative impact on stake holder's value even in SACCOs and it therefore means that good risk management enhances financial performance. According to Dorfman (2007), ensuring that an organization makes cost effective use of risk management first involves creating an approach built up of well-defined risk management and then embedding them. Credit risk identification and credit risk assessment are critical for any lending institution including SACCOs

\subsection{Modern Portfolio Theory}

The portfolio theory is an investment approach in which the investor balances risk against expected return to maximize earnings from an entire portfolio (Markowitz, 1959). Portfolio theory deals with the selection of portfolios that maximize expected returns consistent with the individual acceptable levels of risk. The theory provides a framework for specifying and measuring investment risk and to develop relationships between risk and expected returns. Its main basic assumption is that investors often want to maximize returns from their investments for a given level of risk. The full spectrum of investments must be considered because the returns from all these investments interact hence the relationship between the returns for assets in the portfolio is important (Reilly \& Brown, 2011).

This theory addresses the risk monitory variable. The modern portfolio theory demonstrates that organizations manage their businesses on a portfolio basis to ensure its performance and profitability to the SACCO. SACCO members have to be motivated to invest through savings; they need a rate of return that will compensate them for taking on the risk at the end of period of holding given asset(s). It is therefore important for SACCOs to deploy prudent credit management practices in order to instill control within the various portfolios with a target of maximizing returns on each portfolio.

\subsection{Theory of Internal Controls}

According to Kiaritha et al. (2014) a system of effective internal control is a critical component of an organization's management and a foundation for its safe and sound operation. A system of strong internal control can help to ensure that the goals and objectives of an organization will be met, that it will achieve longterm targets and growth in the financial performance. Such a system can also help to ensure that the organization will comply with laws and regulations as well as policies, plans, internal rules and procedures, and reduce the risk of unexpected losses and damage to the organization's reputation (Barnabas, 2011).

Buck and Breuker (2008) declare internal control as a mistake detecting and correcting system; although Mackevičius (2001) state that internal control is defined as a summation of certain rules, norms and means, actually such definitions are identical, but internal control must be related to safety, the rational use of property and the reliability of financial accounting. The theory is relevant to the study because it outlines the 
internal control policies, procedures, measures and mitigations to be followed in the SACCOs. This theory addresses the forth independent variable on risk mitigation and measures which indicates that there should be strategies and policies to deal with credit risk within the SACCO.

Independent Variables

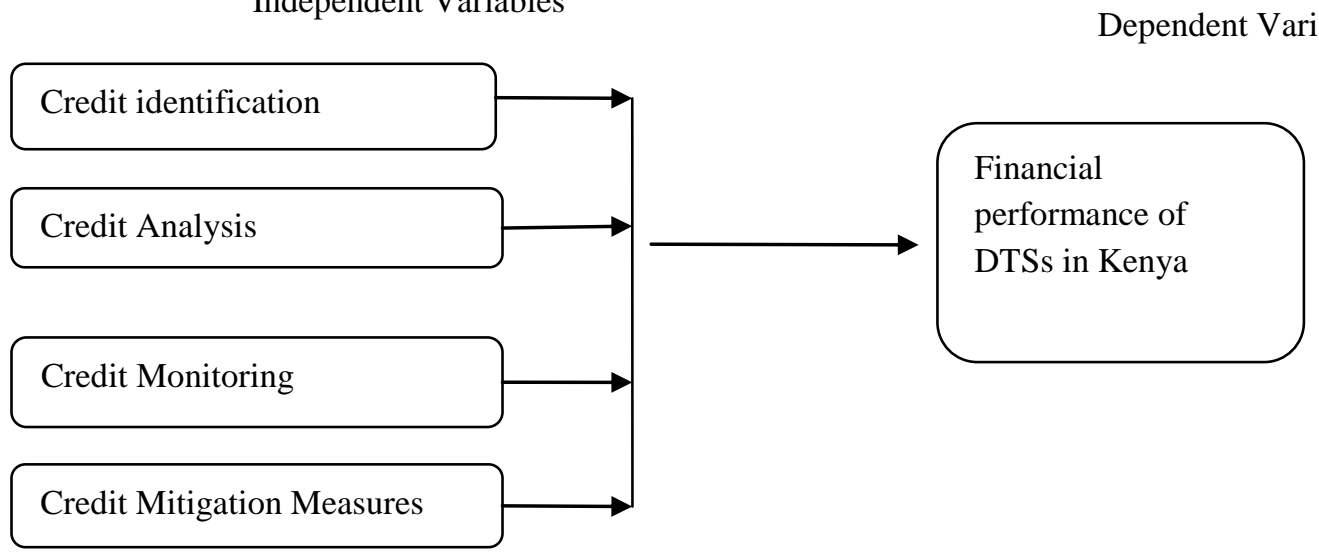

\subsection{Critique of Existing Literature}

A critical review of past literature show that several conceptual and contextual research gaps existed in the effects of credit risk management practices on the financial performance of DTS. For instance, the studies by Soke Fun Ho and Yusoff (2009), in their study on credit risk management strategies of selected financial institutions in Malaysia the majority of financial institutions and banks losses stem from outright default due to inability of customers to meet obligations in relation to lending, trading, settlement and other financial transactions. Credit risk emanates from a bank's dealing with individuals, corporate, financial institutions or sovereign entities. A bad portfolio may attract liquidity as well as credit risk.

Research by (Clement \& Martin, 2012) on the financial practice as a determinant of growth of savings and credit co-operative societies' wealth, the researcher introduced the research very well and offered key definitions. The researcher clearly elaborated the statement of the problem and clearly showed the problem and how he intends to address the issue, the researcher showed the framework and the relationship between the dependent and independent variables very well, the author highlights the key challenges of SACCOs undergo and points out different researches that seem to support his work. The author puts correct research objectives and seems to do a very thorough introduction of the journal. The author has excellent citation related to SACCOs and their progress across a period of time and their growth and eminent challenges they had gone through. The author highlights the research design used and reason behind its usage. The author highlights the sampling and target population and the research instrument and finally comes up with the research model. This guides the research in the right direction to the final conclusion.

Gisemba (2010) also carried out a study on impact of credit risk management practices on financial performance among the SACCOs. He sampled 41 SACCOs and concluded that SACCOs needs 38 management credit risk effective to prevent it from failing in its obligation and meeting its objective, minimize loan defaulters, cash loss and ensures the organization performs better increasing the return on assets and helps the organization in attaining maximum financial returns. The study further concludes that there was a positive relationship between credit risk management practices and the financial performance of SACCOs, depicting the relationship between credit risk management practices and financial performance in organizations. Therefore, it is necessary for SACCOs to have in place comprehensive risk management practices and reporting process to identify, measure, monitor, manage, report and control credit risks. Efficient credit risk management practices have been vital in allowing the phenomenal growth in credit unions. Effective management of credit risk is critical to enhance SACCOs` viability and sustained growth. Failure to control credit risk may lead to insolvency.

Research article by (Odhiambo,2011) on the relationship between working capital management and financial performance of deposit taking savings and credit cooperatives societies licensed by SACCO societies regulatory authority in Nairobi, the researcher cited it was a casual study which leaves a number of question unanswered since this is an academic published journal. The researcher studied four variables which could not wholly address the issue of working capital management in SACCOs. Also the researcher had no econometric model hence it was not possible to verify the form of relationship between dependent and independent variables. 


\subsection{Research Gaps}

Previous studies on credit risk management have not focused on the effects on the credit risk management practices on SACCOs. Ngare (2008) undertook a survey of credit risk management practices by commercial banks in Kenya while Muturi (2010) carried out a survey of techniques or credit risk management in micro-finance institutions in Kenya. This study has critically analyzed credit risk management practices which could be used by conventional financial institutions and suggest ways in which SACCOs can further adapt and innovate to create the optimal risk management culture within their own organizations.

Kithinji (2010) ,Musyoki and Kadubo (2011) analyzed the impact of credit risk management on the financial performance of Banks in Kenya for the period 2000-2006 and concluded that default rate, bad debts costs and cost per loan asset have an inverse impact on banks' financial performance, however the default rate is the most important determinant of bank financial performance vis-à-vis the other indicators of credit risk management. The research had a gap since it did not address the effect of credit risk management practices on profitability and in turn financial performance.

\section{Research Methodology}

This study adopted a descriptive survey design to answer the research questions.. The population of this study comprised of all 164 DTSs in Kenya that have complied with SASRA regulations by January 2016 (Appendix III). Therefore, the study took take censuses approach since the population is not big.

The sampling frame of this study was derived from the database of SASRA which regulates and licenses of deposit taking SACCOs in Kenya. The list of Sacco Societies dated January 2016 which were duly licensed to carry out deposit-taking Sacco business in Kenya in accordance with Section 26(1) of the Act for the financial year ending on 31st December, 2016.

Primary and secondary data was used for the study. Primary data collection technique involved the use of a semi-structured questionnaire containing both open and closed ended questions. The questionnaire was be divided into two sections, A and B. Section A to focus on the profile (demographics) of the responding staff member while section B contained questions aimed at determining the effects of credit risk management on financial performance of Savings and Credit Co-operative Societies in Kenya. The main respondents were credit officers, business unit managers, finance manager and risk managers who had an understanding of credit risk management function in the SACCOs.

The study administered the questionnaire individually to all respondents of the study. The researcher exercised care and control to ensure all questionnaires issued to the respondents were be received and achieve this, the study maintained a register of questionnaires which were sent and received. Secondary data on financial performance and credit risk of the institutions were collected from existing records of the institutions. The study carried out a pilot study to pre-test and validate the questionnaire using 15 SACCOs.

\section{Results and Findings}

\subsection{Effect of Credit Risk Identification on Financial Performance of DTSs}

The first objective of the study was to establish the effect of credit risk identification procedures on the financial performance of SACCO, where the results indicated that the credit risk identification procedures and financial performance had a positive $(\mathrm{r}=0.323)$ and significant $(\mathrm{p}<0.05)$ correlation. The results further showed that $10.4 \%$ of the variance in financial performance was accounted for by the variance in the credit risk identification Lastly, the regression analysis results indicated that credit risk identification had a positive $(\beta=0.005)$ and significant $(p<0.05, p=0.035)$ effect on financial performance.

\subsection{Effect of Credit Analysis Practices on Financial Performance of DTSs}

The second objective of the study was to establish the effect of credit analysis on financial performance and the results from inferential analysis including correlation and regression analysis indicated that there exist a positive $(\mathrm{r}=0.380)$ and significant $(\mathrm{p}=0.012)$ correlation between financial performance and credit analysis practices. Further, the regression results showed that $14.4 \%$ of the variations in financial performance of DTSs is explained by the variations in credit analysis practices. It was also established from regression analysis that credit analysis had a positive $(\beta=0.007)$ and significant $(\mathrm{p}<0.05, \mathrm{p}=0.012)$ effect on financial performance.

\subsection{Effect of Credit Monitoring Practices on Financial Performance of DTSs}

The third objective of the study was to determine the effect of credit monitoring practices on financial performance of DTSs. The Pearson correlation coefficient results indicated that credit monitoring and financial performance. Had a positive $(r=0.692)$ and significant $(\mathrm{p}<0.05)$ correlation. The results further showed that $47.8 \%$ of the variance in financial performance is accounted for by the variance in the credit monitoring practices and further found that credit monitoring practices had a positive $(\beta=0.009)$ and significant effect $(\mathrm{p}<0.05)$ on the financial performance of SACCOs .

DOI: $10.9790 / 487 X-1904026369 \quad$ www.iosrjournals.org $\quad 67 \mid$ Page




\subsection{Effect of Credit Risk Mitigation Measures on Financial Performance of DTSs}

The fourth objective of the study was to evaluate the effect of credit risk mitigation measures on the on financial performance of DTSs and the results Pearson Correlation coefficients indicated that credit risk mitigation measures and SACCO financial performance had a positive $(r=0.417)$ and significant $(p<0.05)$ relationship. The results from analysis further showed that $17.4 \%$ of the variations in financial performance of DTSs were accounted for by the variations in credit risk mitigation measures. Finally, the regression results indicated that credit risk mitigation measures had a positive $(\beta=0.008)$ and significant $(\mathrm{p}<0.05, \mathrm{p}=0.0043)$ effect on financial performance.

\section{Conclusion}

The study concluded that credit risk identification has a positive significant effect on financial performance. This therefore implies that credit risk identification is an essential element that SACCOS and other organizations should pursue as it is linked to performance and in particular for this study it is established to have a positive link with financial performance of SACCOs. As for credit analysis has a significant positive effect on financial performance and thus the implication of this is that a more stringent credit analysis procedure would lead to ensuring that only credit worthy customer's access loans. Credit monitoring also had a positive and significant effect on the financial performance. The implication on this is that credit monitoring ensures that the credit advanced to customers are monitored in terms of repay and thus an effective credit monitoring approach as adopted by SACCOS would therefore ensure that their performance in kept above bar on rather, their financial performance is enhanced as credit default is kept low. While for credit mitigation measures especially in debt collection have a significant positive effect on financial performance of SACCOs. This implies credit risk mitigation measures need to be put in place to ensure that credit advanced to customers are repaid on time and thus ensuring that financial performance is not adversely affected as a result of debt accumulating due to non-repayments.

\section{Recommendations}

From the above findings and conclusions the study also makes for recommendations. The recommendations made are in line with the objectives of the study. First, the study recommends that companies and/or firms should have stringent credit appraisal and analysis techniques if it is to ensure that their performance is not adversely affected resulting from poor screening of debtors. The firms should therefore adopt credit policies that would help improve prudential oversight of asset quality and to establish a set of minimum standards that should be applied before credit is advanced to customers. Further, as borrower selection is the key to successful lending, SACCOs should focus on the selection of true borrower. But at the same time it must be taken into account that right borrower selection does not mean that SACCOs have to adopt conservative lending policy but rather ensure that the seek to adopt knowing the customers so as to ascertain the true purpose of the loan as this would ensure that care is taken so that good borrowers are not discarded due to strict adherence to the lending policy.

The study also recommends that companies and/or firms should also adopt credit monitoring as it was established to have a significant impact on profitability which in turn affects the financial performance. For instance at the branch level credit department must be adequately capable of collecting the correct and relevant information and analyzing the financial statements quickly and precisely. It is also important that credit officers be skilled enough to understand the manipulated and distorted financial statements. To ensure effective monitoring, monitoring of credit should be conducted at regular interval to ensure that the borrower is properly maintaining the credit and utilizing the borrowed money effectively.

It is also recommended that SACCOs and any other credit lending organization should have a stringent credit mitigation measures as the findings indicate that debt collection practices have a significant impact on the financial performance of SACCOs. Therefore the credit committees at all levels must work in co-ordination in order to ensure that credit is collected in a timely manner.

\section{Acknowledgements}

First, my gratitude goes to our Almighty God for His mercies and grace that have enabled me to come this far. I wish to express my sincere gratitude also to my supervisor Dr. Karanja for his immeasurable guidance, support, encouragement and time input that enabled me research and write this thesis proposal. My sincere appreciation also goes to my lecturers, colleagues and staff of JKUAT- CBD Campus for the assistance extended to me in one way or the other.

May the Almighty God bless them all. 


\section{References}

[1] Sambasivam, Y., \&Biruk, A. (2013) Financial Performance analysis of GOHE Co-Operatives Savings and Credit Union in Bure Woreda, Ethiopia. International journal research journal of economics and business studies. 02(06). Retrieved from www.theinternationaljournal. org

[2] Central Bank of Kenya (2011). Bank Supervision Annual Report. Retrieved from https://www.centralbank.go.ke

[3] Ngare, E. M. (2008). A Survey of Credit Risk Management Practices by Commercial Banks in Kenya. (Published Masters Thesis) University of Nairobi. Retrieved from http://erepository.uonbi.ac.ke

[4] Muruti, J. N (2010). Credit Risk Management Practices Adopted By Microfinance Institutions in Kenya . (Published Masters Thesis) University of Nairobi. Retrieved from http://erepository.uonbi.ac.ke

[5] Sammy, A., Philemon. B., \&Juma., (2013) Analysis of Financial Mismatch in Co-Operative Societies: A Case of Kakamega County, Kenya. International Journal for Management Science and Technology (IJMST). 1(5), 2321-0362.

[6] SACCO Societies Regulatory Authority (SASRA) (2012). SACCO Supervision Report: Deposit Taking SACCOs. In house Publication.

[7] SACCO Societies Regulatory Authority (SASRA) (2014). SACCO Annual Report . In house Publication

[8] Barrales R. J. (2012), A Best Practices Approach to Risk Management, TMA Journal, Jan/Feb, 30-34.

[9] Ministry of Co-operative Development and Marketing, (2008) .Co-operative Development Policy, Nairobi, Ministry of Co-operative Development and Marketing.

[10] Alfred, O. (2011). Corporate Governance and Financial Performance of SACCOs in Lango Sub Region. Unpublished Masters Thesis, Makerere University-Kampala.

[11] Njeru( 2016) Effect of Liquidity Management on Financial Performance of Deposit Taking Saving and Credit Co-Operative Society in Kenya. (Published PHD Thesis) Jomo Kenyatta University of Agriculture and Technology. Retrieved from http://ir.jkuat.ac.ke

[12] Bessis, J. (2003) Risk Management in banking (2nd edition), John Wiley \& Sons, Chichester, New York.

[13] Opondo, M. (2014) The Effect of Credit Risk Management on the Financial Performance of Commercial Banks in Kenya. (Published Masters Thesis) University of Nairobi. Retrieved from http://erepository.uonbi.ac.ke

[14] Wenk , L.A.M. (2010). Risk exposure during the global financial crisis: the case of Islamic banks, International Journal of Islamic and Middle Eastern Finance and Management, 3 (4), 321-33.

[15] Kirigo M. W. (2014). The effect of risk management on financial performance of Commercial banks in Kenya. (Published Masters Thesis) University of Nairobi. Retrieved from http://erepository.uonbi.ac.ke

[16] Dorfman, H. (2007). Risk management: an analysis of issues in Islamic financial industry. IRTI, Jeddah, Occasional Paper No. 5.

[17] Reilly, F. K.\& Brown, K. C.(2011). Investment Analysis and Portfolio Management. Australia: South-Western.

[18] Kiaritha H. ,Mouni G. and Mung'atu J.(2014) Effect of operating costs on the financial performance of SACCOs in the banking sector in Kenya. Prime Journal of Business Administration and Management (BAM) ISSN: 2251-1261. Vol. 4(2), pp. 1359-1363, January 22nd, 2014

[19] Barnabas, C. (2011). Internal Control. Cede Publishing, $144 \mathrm{p}$

[20] Clement, O., \& Martin, O. (2012) Financial Practice as a Determinant of Growth of Savings and Credit Co-Operative Societies' Wealth. (A Pointer to Overcoming Poverty Challenges in Kenya and the Region). International Journal of Business and Social Science, 24(3), 204-219 